\title{
Analisis Efisiensi Pelaksanaan Sistem Informasi Pengelolaan Inventarisasi Aset Daerah Pada Kecamatan Purwokerto Selatan
}

\author{
Ria Manurung ${ }^{1}$, Miftha Rizkina² \\ ${ }^{1}$ Komputerisasi Akuntansi, Sekolah Tinggi Ilmu Komputer Yos Sudarso, \\ Jalan SMP 5 Karang Klesem, Purwokerto 53144 \\ ${ }^{2}$ Akuntansi, Universitas Pembangunan Panca Budi, \\ Jalan Jend. Gatot Subroto Km. 4,5 Sei Sikambing, Medan 20122
}

Received: DD MM YY - Revised: DD MMYY - Accepted: DD MM YY - Published: 280921

\begin{abstract}
Abstrak. Tujuan penelitian yaitu mengelola data inventarisasi aset daerah di kantor kecamatan Purwokerto Selatan menjadi efisien, cepat dan akurat. Evaluasi terhadap pelaksanaan sistem informasi inventarisasi aset dilakukan untuk menilai sejauh mana efisiensi dan manfaat yang dapat dicapai. Metode yang digunakan untuk penelitian adalah wawancara, observasi, survei dan kepustakaan. Metode Pengembangan Sistem menggunakan metode System Development Life Cycle (SDLC) dengan model Waterfall. Uji Hipotesis menggunakan Paried Sampel t-Test untuk membandingkan waktu dan banyaknya jumlah barang yang diinventarisasi sebelum dan sesudah menggunakan sistem informasi inventarisasi aset dengan alat bantu aplikasi SPSS. Uji Normalitas menggunakan Kolmogorov-Smirnov untuk mengetahui persebaran data apakah terdistribusi normal atau tidak. Pengujian terhadap sistem menggunakan metode White-Box Testing dan Black-Box Testing. Metode penentuan sampel penelitian dengan purposive sampling yang berjumlah 30 responden dengan kriteria yang dapat mengoperasikan komputer, merupakan pegawai PNS di kantor kecamatan Purwokerto Selatan dan di kantor kecamatan Purwokerto Barat. Penentuan jumlah populasi sebanyak 33 orang dengan menggunakan Rumus Slovin. Hasil penelitian yang diperoleh dari uji hipotesis yaitu parameter waktu yang menghasilkan mean waktu sebesar 13,4917 menit sebelum adanya sistem informasi inventarisasi aset dan mean waktu sesudah adanya sistem informasi inventarisasi aset yaitu sebanyak 3.2533 menit. Hasil yang diperoleh dari uji manfaat yaitu rata-rata untuk indikator "Kegunaan" sebesar 84\%, "Mudah Dipelajari" sebesar 82\%, "Efisiensi" yaitu $88 \%$ dan "Akurat" sebesar 87\%. Kesimpulan penelitian bahwa Sistem Informasi Inventarisasi Aset Daerah Kecamatan Purwokerto Selatan sangat efisien sebagai alternatif pengelolaan inventarisasi aset.
\end{abstract}

Kata kunci: Waterfall, Inventarisasi, Aset, Hipotesis, Purposive sampling

Citation Format: Manurung, R. Rizkina, M. (2020). Analisis Efisiensi Pelaksanaan Sistem Informasi Pengelolaan Inventarisasi Aset Daerah Pada Kecamatan Purwokerto Selatan. Prosiding Seminar Nasional Abdimas Ma Chung (SENAM), 2020, 114-124 


\section{PENDAHULUAN}

Kantor Kecamatan Purwokerto Selatan merupakan salah satu kantor yang berada di wilayah Purwokerto yang terdiri dari 4 kecamatan yaitu Kecamatan Purwokerto Selatan, Barat, Utara dan Timur. Purwokerto adalah ibu kota Kabupaten Banyumas yang berada di wilayah Propinsi Jawa Tengah. Kantor Kecamatan merupakan instansi pemerintah yang bergerak di bidang pelayanan masyarakat. Kelemahan dalam kegiatan pelayanan di kantor kecamatan Purwokerto Selatan yaitu pengelolaan dan penyimpanan data inventaris aset yang dalam hal ini adalah barang inventarisasi dilakukan secara manual dengan menggunakan buku besar. Sehingga untuk catatan barang-barang di tahun-tahun sebelumnya sebagian sudah tidak ada lagi karena pengelolaan yang digunakan masih sangat sederhana. Apabila ada pihak yang membutuhkan data-data barang tersebut maka akan kesulitan untuk menemukannya atau membutuhkan waktu yang lama untuk mencari data barang tersebut. Fakta yang ditemukan juga yakni sebagian barang tidak ada lagi wujudnya namun masih terdaftar di buku besar dan beberapa barang yang ada wujudnya namun tidak tercatat dalam buku besar. Hal ini disebabkan karena keamanan data masih kurang terjamin serta proses penyediaan informasi cukup lama karena membutuhkan waktu dalam pencatatan secara manual. Dalam upaya mengatasi semua permasalahan tersebut, maka perlu solusi yang tepat guna yaitu sistem informasi untuk mengelola inventarisasi aset daerah pada kantor kecamatan di Purwokerto Selatan. Dengan adanya Sistem Informasi Pengelolaan Inventarisasi Aset Daerah ini, diharapkan pengelolaan data inventarisasi aset daerah di kantor kecamatan akan lebih efisien, cepat dan akurat. Evaluasi terhadap pelaksanaan sistem informasi inventarisasi aset ini dilakukan untuk menilai sejauh mana efisiensi dan manfaat yang dapat dicapai.

\section{METODE PELAKSANAAN}

Metode yang digunakan untuk penelitian ini yaitu :

1. Wawancara yaitu untuk mendapatkan data dengan cara melakukan komunikasi dua arah antara peneliti dan responden yang dalam hal ini adalah Kepala Camat dan petugas bagian inventaris. barang, dan peluangnya.

2. Observasi merupakan pengukuran data dengan melakukan peninjauan langsung ke tempat dilakukannya penelitian yang dalam hal ini adalah di kantor Kecamatan Purwokerto Selatan, dengan mengamati objek data dan sistem yang sedang berjalan di kantor Kecamatan Purwokerto Selatan. 
3. Survei adalah metode pengumpulan data primer dengan memberi batasan yang jelas atas data yang dikumpulkan dengan cara memberikan daftar pertanyaan kepada responden dalam bentuk kuisioner (Paath \& Manurung, 2019).

4. Kepustakaan yaitu metode pengumpulan data sekunder yang dilakukan dengan cara mencari referensi artikel yg dipublikasikan di jurnal, prosiding dan referensi dari bukubuku ilmiah untuk mendukung penelitian (Durahman \& Munir, 2019).

5. Metode Pengembangan Sistem dalam penelitian ini menggunakan metode System Development Life Cycle (SDLC) dengan model Waterfall menurut (Sataria \& Siahaan, 2018) terdiri dari tahapan-tahapan sebagai berikut :

1) Analisis Kebutuhan

2) Desain Sistem

3) Implementasi \& Pengujian Unit

4) Pengujian Sistem

5) Maintenance

6) Evaluasi Sistem

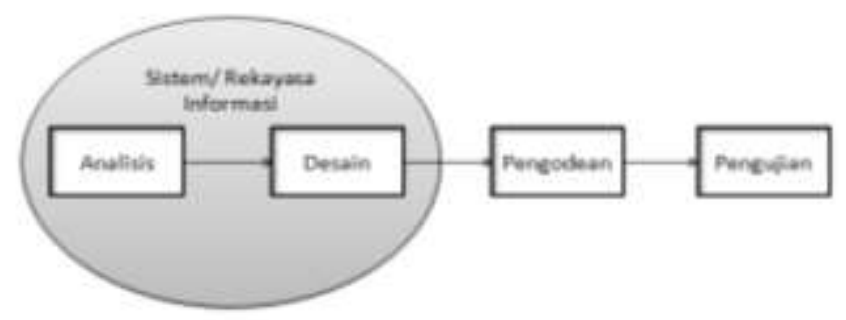

Gambar 1. Ilustrasi model Waterfall

6. Metode untuk evaluasi sistem terdiri dari 5 proses menurut (Maulidiya Kasrina \& Kasrina Della, 2016) yaitu :

a. Pengumpulan Sumber Data untuk pengujian hipotesis adalah data kuantitatif berupa waktu dan banyaknya jumlah barang yang diinventarisasi sebagai data ratio yang diperoleh secara langsung sebelum dan sesudah menggunakan sistem informasi inventarisasi. Sedangkan sumber data untuk pengujian manfaat sistem informasi inventarisasi adalah data kualitatif berupa kuesioner yang disebarkan kepada para responden.

b. Menentukan Hipotesis untuk penelitian ini adalah:

Ho: Tidak ada perbedaan waktu dan kevalidan data yang signifikan dalam pengelolaan inventarisasi aset daerah sebelum dan sesudah menggunakan Sistem Informasi Inventarisasi Aset Daerah. 
Hi: Ada perbedaan waktu dan kevalidan data yang signifikan dalam pengelolaan inventarisasi aset daerah sebelum dan sesudah menggunakan Sistem Informasi Inventarisasi Aset Daerah.

c. Uji Normalitas menggunakan Kolmogorov-Smirnov untuk mengetahui persebaran data apakah terdistribusi normal atau tidak (Wijoyo \& Hermanto, 2020).

d. Uji Hipotesis menggunakan Paried Sampel t-Test untuk membandingkan waktu dan banyaknya jumlah barang yang diinventarisasi sebelum dan sesudah menggunakan sistem informasi inventarisasi aset dengan alat bantu aplikasi SPSS (R Manurung, 2016).

e. Interpretasi Hasil adalah kesimpulan yang akan menyatakan diterima atau ditolak Ho. Penolakan Ho berdasarkan tingkat signifikansi (x) untuk mendapatkan t hitung. Jika tingkat signifikansi $(\mathrm{x})<0,05$ maka Ho ditolak, jika $(\mathrm{x})>0,05$ maka Ho diterima $(\mathrm{R}$ Manurung \& Paath, 2020).

7. Pengujian terhadap sistem yang dilakukan peneliti terdiri dari 2 metode menurut (Subagia et al., 2020) yaitu:

1) White-Box Testing yaitu cara pengujian dengan melihat ke dalam modul untuk meneliti kode-kode program yang ada dan menganalisis apakah ada kesalahan atau tidak. Jika ada modul yang menghasilkan output yang tidak sesuai dengan proses bisnis yang dilakukan maka baris-baris program, variabel, dan parameter yang terlibat pada unit tersebut akan dicek satu persatu dan diperbaiki, kemudian dicompile ulang.

2) Black-Box Testing yaitu pengujian yang dikonsentrasikan terhadap unit program apakah memenuhi kebutuhan (requirement) yang disebutkan dalam spesifikasi. Cara pengujian dilakukan dengan mengeksekusi unit atau modul, kemudian diamati apakah hasil dari unit sesuai dengan proses bisnis yang dibutuhkan.

8. Uji Manfaat yakni untuk mengetahui apakah Sistem Informasi Inventarisasi Aset Daerah Pada Kecamatan Purwokerto Selatan dapat digunakan dan bermanfaat untuk efisiensi, cepat, dan akurat dalam pengelolaan inventarisasi aset daerah.

9. Metode penentuan sampel penelitian dengan purposive sampling yaitu peneliti menentukan kriteria sampel. Sampel berjumlah 30 responden dengan kriteria sampel adalah yang dapat mengoperasikan komputer, merupakan pegawai PNS di kantor kecamatan Purwokerto Selatan dan di kantor kecamatan Purwokerto Barat sebagai tetangga kantor kecamatan terdekat. Penentuan jumlah populasi yaitu dengan menggunakan Rumus Slovin (Prehanto, 2015) yakni: 
$\mathrm{n}=\mathrm{N} /\left(1+\mathrm{N}(\mathrm{e})^{2}\right)$

Dengan ketentuan :

$\mathrm{n}=$ ukuran sampel

$\mathrm{N}=$ populasi

$\mathrm{e}=$ tingkat persentase kelonggaran atau ketidaktelitian/ kesalahan

Jumlah populasi $(\mathrm{N})$ ditentukan sebanyak 33 maka jumlah sampel sebanyak 30 orang dengan perhitungan sebagai berikut:

$$
\begin{aligned}
\mathrm{n} & =\mathrm{N} /\left(1+\mathrm{N}(\mathrm{e})^{2}\right) \\
& =33 /\left(1+33(0.05)^{2}\right) \\
& =33 / 1,0825 \\
& =30,4 \rightarrow \text { pembulatan } 30 \text { orang }
\end{aligned}
$$

Rincian sampel yaitu camat dan pegawai kantor kecamatan Purwokerto Selatan sebanyak 20 orang dan pegawai kantor kecamatan Purwokerto Barat sebanyak 10 orang dengan kriteria dapat mengoperasikan komputer atau laptop dan status sebagai pegawai PNS di kantor kecamatan tersebut.

10. Pengembangan sistem pada penelitian meliputi seluruh entitas yang terlibat dan arah arus data yang masuk dan ke luar melalui sistem (Irnawati \& Darwati, 2020) seperti yang dapat dilihat pada diagram konteks berikut ini :

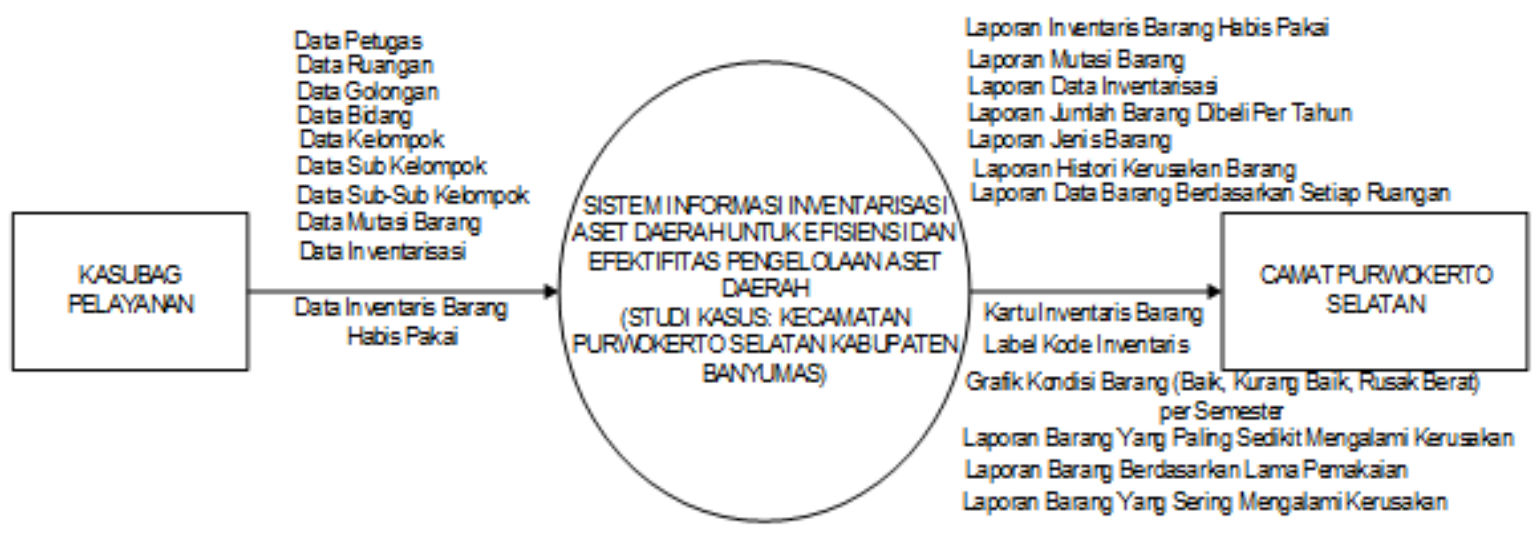

Gambar 2. Diagram Konteks Sistem Informasi Inventarisasi Aset

Model pengembangan data Entity Relationship Diagram (ERD) digunakan untuk menjelaskan hubungan antara data pada database dengan user secara terstruktur (Ibeng, 2018) seperti gambar ERD di bawah ini. 


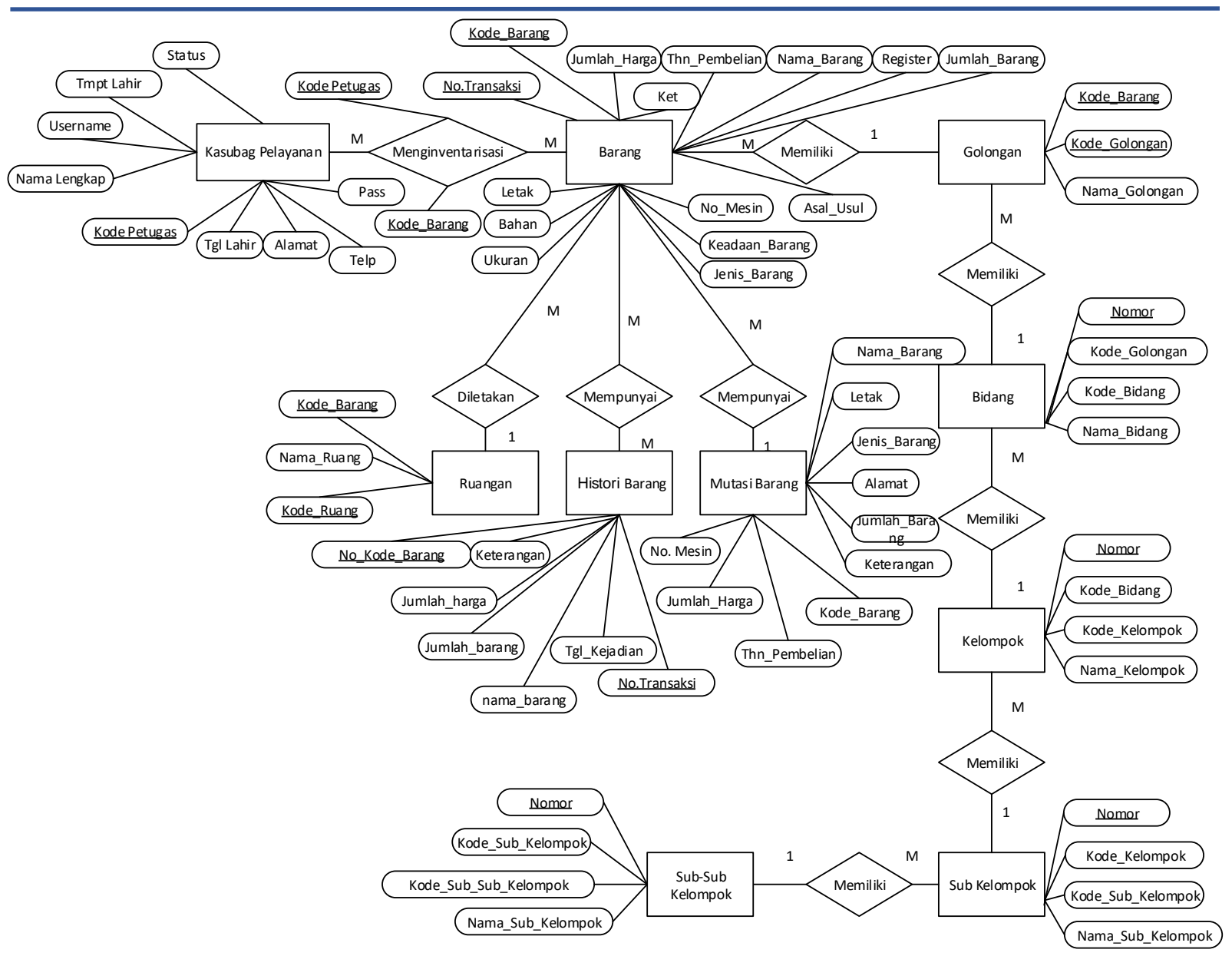

Gambar 3. ERD Sistem Informasi Inventarisasi Aset Daerah

\section{HASIL DAN PEMBAHASAN}

\section{Implementasi Perancangan Antarmuka Inventarisasi Aset Daerah}

a. Halaman tampilan utama Inventarisasi Aset Daerah terdiri dari Login yang berfungsi sebagai penunjang akses utama untuk masuk ke dalam sistem informasi inventarisasi aset daerah dan Exit berfungsi sebagai pembatalan untuk masuk ke sistem informasi.

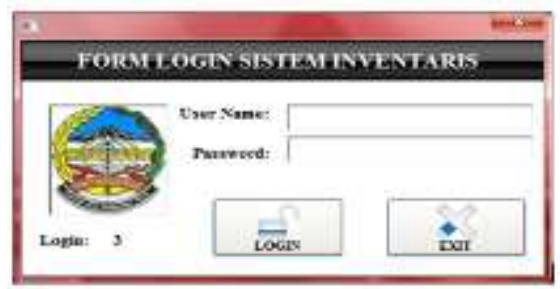

Gambar 4. Form Login

b. Menu Utama terdiri dari enam menubar yaitu File, Master Data, Transaksi, Laporan, Setting dan Tools seperti pada gambar berikut. 


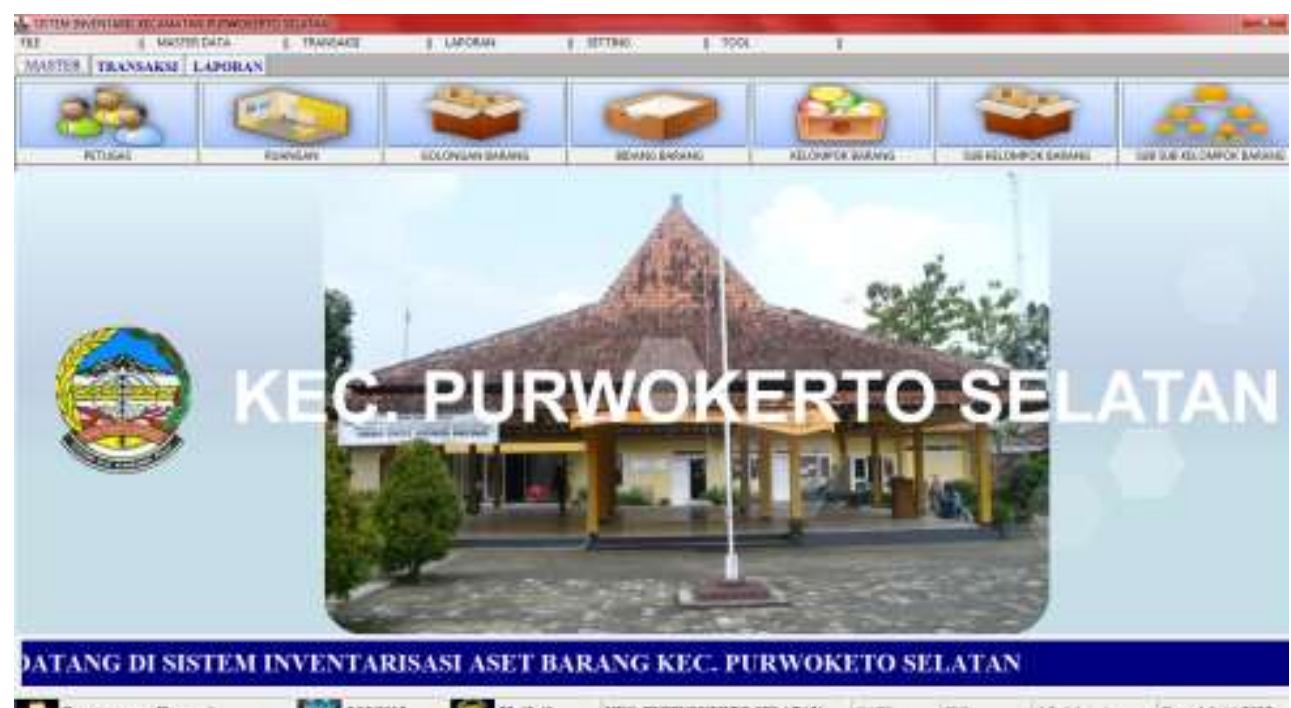

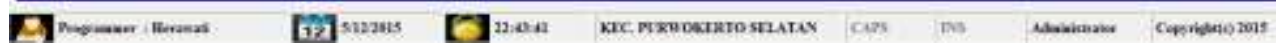

Gambar 5. Form Menu Utama

\section{Uji Normalitas}

Data yang diperoleh diuji normalitasnya dengan menggunakan Chi Square model untuk mengetahui apakah persebaran data normal atau tidak (Ria Manurung, 2019). Dasar pengambilan keputusan yaitu Jika sig > 0,05 maka distribusi data dinyatakan normal dan jika sig $<0,05$ maka distribusi data dinyatakan tidak normal. Hasil pengujian dapat dilihat pada tabel berikut ini:

Tabel 1. One Sample Chi Square Test

\begin{tabular}{cccc}
\multicolumn{4}{c}{ Test Statistics } \\
\hline & $\begin{array}{c}\text { waktu } \\
\text { sebelum } \\
\text { menggunakan } \\
\text { sistem }\end{array}$ & $\begin{array}{c}\text { kaktu sesudah } \\
\text { menggunakan } \\
\text { sistem }\end{array}$ & $\begin{array}{c}\text { Kevalidan } \\
\text { data sebelum } \\
\text { menggunakan } \\
\text { sistem }\end{array}$ \\
\hline Chi-Square & $\mathbf{1 . 7 3 3}^{\text {a }}$ & $\mathbf{5 . 0 0 0}^{\text {b }}$ & $\mathbf{2 4 . 3 3 3}^{\mathbf{c}}$ \\
df & 27 & 24 & 4 \\
Asymp. Sig. & 1.000 & 1.000 & $\mathbf{. 0 0 0}$ \\
\hline
\end{tabular}

a. 28 cells $(100.0 \%)$ have expected frequencies less than 5 . The minimum expected cell frequency is 1.1 .

b. 25 cells $(100.0 \%)$ have expected frequencies less than 5 . The minimum expected cell frequency is 1.2.

c. 0 cells $(.0 \%)$ have expected frequencies less than 5 . The minimum expected cell frequency is 6.0.

Pada tabel One-sample chi squer test dapat dilihat bahwa nilai asymp.sig 1,000 dan 1,000.

Dengan demikian data dinyatakan terdistribusi normal karena nilai signifikansinya $>0,05$.

\section{Uji Hipotesis}

Tabel 2. Paired Samples Test 


\section{Paired Samples Test}

\section{Paired Differences}

95\% Confidence

Interval of the

Difference

Std.

Std. Error

Sig. (2-

\begin{tabular}{|c|c|c|c|c|c|c|c|c|c|}
\hline & & Mean & Deviation & Mean & Lower & Upper & $\mathbf{t}$ & df & tailed) \\
\hline Pair 1 & $\begin{array}{l}\text { waktu sebelum } \\
\text { menggunakan } \\
\text { sistem - waktu } \\
\text { sesudah } \\
\text { menggunakan } \\
\text { sistem }\end{array}$ & $\begin{array}{c}10.2383 \\
3\end{array}$ & .72123 & .13168 & 9.96902 & $\begin{array}{c}10.5076 \\
4\end{array}$ & 77.753 & 29 & .000 \\
\hline Pair 2 & $\begin{array}{l}\text { Kevalidan data } \\
\text { sebelum } \\
\text { menggunakan } \\
\text { sistem - Kevalidan } \\
\text { data sesudah } \\
\text { menggunakan } \\
\text { sistem }\end{array}$ & -.16667 & .21064 & .03846 & -.24532 & -.08801 & -4.334 & 29 & .000 \\
\hline
\end{tabular}

Tabel Paired Samples Test di atas menjelaskan hasil uji sampel berpasangan yang berupa nilai t hitung dan tingkat signifikan dengan tingkat kepercayaan 95\%. Pengambilan keputusan berdasarkan signifikasi:

a. Pada Tabel 2 dapat dilihat bahwa nilai signifikan yang diperoleh adalah 0,000 .

b. Pengambilan keputusan didasarkan pada ketentuan jika nilai signifikan >0,005 maka Ho dterima, sebaliknya jika signifikansi $<0,005$ maka $\mathrm{H} 0$ ditolak yang berartti $\mathrm{H} 1$ diterima. Maka kesimpulan nya yaitu signifikansi pada output sebesar 0,000 $<0,005$ maka Ho ditolak yang berarti $\mathrm{H} 1$ diterima yaitu ada perbedaan waktu dan tingkat akurasi sebelum dan sesudah menggunakan sistem informasi inventarisasi aset daerah.

\section{Uji Reliabilitas}

Tabel 3. Hasil Uji Reliabilitas

Case Processing Summary

\begin{tabular}{llrr}
\hline & \multicolumn{2}{c}{$\%$} \\
\hline Cases & Valid & 30 & 100.0 \\
& Excluded $^{\mathrm{a}}$ & 0 & .0 \\
& Total & 30 & 100.0 \\
\hline
\end{tabular}

Tabel 4. Reliability Statistics 


\section{Reliability Statistics}

\section{Cronbach's $\mathrm{N}$ of Items \\ Alpha}

.737

21

Pada tabel Case processing Summary diperoleh data valid sebanyak 30 dan dari tabel Reliability Statistics diperoleh nilai cronbach's alpha sebesar 0.737 dengan jumlah item sebanyak 21 karena nilai lebih dari 0.7 maka dapat disimpulkan bahwa item pertanyaan dinyatakan reliable.

\section{Uji Manfaat}

Hasil pengolahan jawaban responden untuk uji manfaat dapat dilihat pada tabel 5 berikut ini dengan menggunakan skala Likert yaitu kriteria Setuju $=$ S, Sangat Setuju $=$ SS, Sangat Tidak Setuju = STS, dan Tidak Setuju = TS (Hertanto, 2017).

Tabel 5. Rangkuman Uji Manfaat (dalam \%)

\begin{tabular}{|c|c|c|c|c|c|c|c|}
\hline \multirow[t]{5}{*}{ Kegunaan } & \multirow{2}{*}{ Kriteria } & \multicolumn{5}{|c|}{ Pertanyaan } & \multirow{2}{*}{ Rata-rata } \\
\hline & & V1 & V2 & V3 & V4 & V5 & \\
\hline & \multirow{3}{*}{$\begin{array}{c}\text { S } \\
\text { SS }\end{array}$} & 66 & 70 & 70 & 60 & 56 & \multirow{3}{*}{84} \\
\hline & & 17 & 17 & 13 & 23 & 27 & \\
\hline & & 83 & 87 & 83 & 83 & 83 & \\
\hline \multirow[t]{4}{*}{ Mudah Dipelajari } & \multirow{2}{*}{ Kriteria } & \multicolumn{5}{|c|}{ Pertanyaan } & \multirow{2}{*}{ Rata-rata } \\
\hline & & V6 & V7 & V8 & V9 & V10 & \\
\hline & $S$ & 23 & 57 & 33 & 53 & 54 & \multirow{3}{*}{82} \\
\hline & SS & 54 & 23 & 47 & 37 & 30 & \\
\hline Total & & 77 & 80 & 80 & 90 & 84 & \\
\hline \multirow[t]{4}{*}{ Efisiensi } & \multirow{2}{*}{ Kriteria } & \multicolumn{5}{|c|}{ Pertanyaan } & \multirow{2}{*}{ Rata-rata } \\
\hline & & V11 & V12 & V13 & V14 & V15 & \\
\hline & $\mathrm{S}$ & 60 & 56 & 54 & 60 & 67 & \multirow{3}{*}{88} \\
\hline & SS & 27 & 27 & 33 & 34 & 23 & \\
\hline Total & & 87 & 83 & 87 & 94 & 90 & \\
\hline \multirow[t]{4}{*}{ Akurat } & & \multicolumn{5}{|c|}{ Pertanyaan } & \multirow{2}{*}{ Rata-rata } \\
\hline & Kriteria & V16 & V17 & V18 & V19 & V20 & \\
\hline & $S$ & 67 & 56 & 77 & 57 & 50 & \\
\hline & SS & 27 & 27 & 10 & 23 & 43 & 87 \\
\hline Total & & 94 & 83 & 87 & 80 & 93 & \\
\hline
\end{tabular}

Keterangan:

V1 - V20 : variabel pertanyaan 1 sampai 20 pada kuesioner uji manfaat

$S$ : Setuju

SS : Sangat Setuju

Tabel 6. Persentase Hasil Uji Manfaat 


\begin{tabular}{cccc}
\hline Kegunaan & Mudah Dipelajari & Efisiensi & Akurat \\
\hline 84 & 82 & 88 & 87 \\
\hline
\end{tabular}

Pada tabel 5 dan 6 dapat dilihat bahwa hasil uji manfaat yang dilakukan memperoleh kesimpulan yaitu persentase jawaban kriteria setuju dan sangat setuju lebih besar dibandingkan dengan jawaban kriteria tidak setuju dan sangat tidak setuju.

\section{Interpretasi hasil}

Hasil yang ditampilkan pada tabel rangkuman Uji Manfaat dan persentase hasil Uji Manfaat dapat diketahui bahwa persentase terbesar dari tiap parameter dengan kriteria jawaban setuju dan sangat setuju yang lebih besar. Pada tabel persentase menunjukkan bahwa indikator “Kegunaan” sebesar 84\%, "Mudah dipelajari” sebesar 82\%, "Efisiensi” sebesar 88\%, dan “Akurat" sebesar 87\%. Sehingga dapat disimpulkan bahwa Sistem Informasi Inventarisasi Aset Daerah Kecamatan Purwokerto Selatan sangat berguna dan Efisien sebagai alternatif pengelolaan laporan inventarisasi barang yang mempunyai keunggulan-keunggulan berdasarkan kegunaan, kemudahan mempelajari, efisiensi sistem dan keakuratan data.

\section{KESIMPULAN}

Hasil yang diperoleh dari uji hipotesis yaitu parameter waktu yang menghasilkan mean waktu sebesar 13,4917 menit sebelum adanya sistem informasi inventarisasi aset dan mean waktu sesudah adanya sistem informasi inventarisasi aset yaitu sebanyak 3.2533 menit. Hasil yang diperoleh dari uji manfaat yaitu rata-rata untuk indikator "Kegunaan" sebesar 84\%, “Mudah Dipelajari” sebesar 82\%, "Efisiensi” yaitu 88\% dan "Akurat” sebesar 87\%.

Sehingga dapat disimpulkan bahwa Sistem Informasi Inventarisasi Aset Daerah Kecamatan Purwokerto Selatan sangat efisien sebagai alternatif pengelolaan inventarisasi aset. Sistem ini mempunyai keunggulan berdasarkan kegunaan, kemudahan mempelajari, efisiensi sistem dan keakuratan data jika dibandingkan dengan inventarisasi secara manual.

\section{DAFTAR PUSTAKA}

Durahman, N., \& Munir, S. (2019). Sistem Informasi Inventaris Data Barang Di Pt Nata Bersaudara Sejahtera Menggunakan Metode Garis Lurus. Jurnal Teknik Informatika.

Hertanto, E. (2017). Perbedaan Skala Likert Lima Skala Dengan Modifikasi Skala Likert Empat Skala. Metodologi Penelitian. 
Ibeng. (2018). Pengertian Entity Relationship Diagram (ERD). Www.Pendidikanku.Org.

Irnawati, O., \& Darwati, I. (2020). Penerapan Model Waterfall Dalam Analisis Perancangan Sistem Informasi Inventarisasi Berbasis Web. JURTEKSI (Jurnal Teknologi Dan Sistem Informasi). https://doi.org/10.33330/jurteksi.v6i2.406

Manurung, R. (2016). Sistem Informasi Inventory dan Penggajian Sales Distributor Sparepart Motor Untuk UD. Berkah Abadi Purwokerto. Media Aplikom.

Manurung, R, \& Paath, D. K. (2020). Pengaruh Regulasi Digital Cryptocurrency Model Bitcoin Terhadap Sistem Pembayaran Pada UMKM. @ Is The Best: Accounting Information ....

Manurung, Ria. (2019). Perancangan dan Analisis Sistem Informasi Persediaan Barang pada CV UMA HANA. Jurnal Sistem Dan Informatika (JSI). https://doi.org/10.30864/jsi.v14i1.239

Maulidiya Kasrina, D. K., \& Kasrina Della, K. M. (2016). Pengembangan Modul Inventarisasi Tanaman Obat Pada Sistem Informasi Tanaman Obat Bengkulu. Jurnal Media Infotama.

Paath, D. K., \& Manurung, R. (2019). Analisis Persepsi Pengguna Layanan Transaksi Digital Terhadap Financial Technology (Fintech) Dengan Model E-Money (Studi kasus: layanan Go-Pay "Gojek” di Purwokerto). Jurnal HUMMANS.

Prehanto, D. R. (2015). Rancang Bangun Sistem Informasi Inventarisasi Peralatan dan Bahan Laboratorium Berbasis Web di Jurusan Teknik Elektro UNESA. Jurnal Manajemen Informatika.

Sataria, I., \& Siahaan, K. (2018). Analisa dan Perancangan Sistem Informasi Inventarisasi Barang Milik Negara (BMN) Kantor DPD RI di Ibukota Provinsi Berbasis Web pada Sekretariat Jenderal DPD RI. Jurnal Manajemen Sistem Informasi.

Subagia, R., Alit, R., \& Akbar, F. A. (2020). Pengujian white box pada sistem informasi monitoring skripsi program studi informatika. Jurnal Informatika Dan Sistem Informasi (JIFoSI).

Wijoyo, A. C., \& Hermanto, D. (2020). Analisis dan Perancangan Sistem Informasi Inventory pada PT Insan Data Permata. Jurnal Riset Dan Aplikasi Mahasiswa Informatika (JRAMI). https://doi.org/10.30998/jrami.v1i02.231

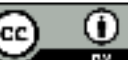

(C) 2021 by authors. Content on this article is licensed under a Creative Commons Attribution 4.0 International license. (http://creativecommons.org/licenses/by/4.0/). 